\title{
The Right to Protect Children under International Law: The Case of Child Soldiers
}

\author{
Enarda Cuni, LL.M. \\ St.Thomas University, Miami, USA \\ ecuni@stu.edu \\ Juelda Lamce, PhD. \\ Lecturer at European University of Tirana \\ juelda.lamce@yahoo.com
}

\section{Doi:10.5901/ajis.2013.v2n8p670}

\begin{abstract}
Currently, there are tens of thousands of child soldiers among the ranks of combatants in international and internal armed conflicts around the world. While many child soldiers commit heinous acts that constitute war crimes, the reality is that many child soldiers, especially the youngest of them, are war victims even as they perpetrate atrocities that shock the conscience of men. This article examines the plight of child soldiers and the collective duties of nations in their commitments under international law to protect the fundamental human rights of children subjected to conflict. The article will then look at the international law intended to protect children in conflict zones and what standards should be applied in determining how child soldiers should be treated, either as war criminals or as victims of conflict. Next, the article will look at the responsibility nations have to protect children from becoming combatants or being re- recruited into emerging armed conflicts, to prosecute those who use children as combatants; to help children in process of rehabilitation or reintegration; to educate the citizens about the plight of child soldiers and the factors that place children at risk of becoming child soldiers.
\end{abstract}

Keywords: child soldiers, armed conflict, recruitment, international law, international humanitarian law, legal standards

\section{Introduction}

One of the most alarming and dangerous characteristics of modern armed conflicts is the increasingly widespread employment of children as soldiers. Child soldiers are found on each continent, in nearly every major armed conflict in the world today. Traditionally, children were protected by cultural presumptions that they were noncombatants. The first widespread use of child soldiers was in the Second World War. ${ }^{1}$ Approximately 300.000 children are used in both international and national conflicts around the world. Twenty million children have died as a result of participation in armed conflicts. ${ }^{2}$

Over the past two decades, the international child rights movement has prompted the development of international law, policies and programs concerning the use of child soldiers. Yet in spite of the stronger laws and advocacy that have resulted in UN's Security Council resolutions, international agreements, domestic legislation and establishment of country specific ad hoc tribunals, both national armies and rebel groups continue to recruit and use children in armed conflicts. In the twentieth century, children have increasingly become the direct and indirect victims of armed conflict. The twentieth century has also seen the rise of the concept of children's rights, most recently encoded in the United Nations Convention on the Rights of the Child. ${ }^{3}$ Neither humanitarian law (including the Geneva Conventions of 1949 and the Additional Protocols to the Geneva Conventions of 1977) nor human rights law has managed, as yet, to reduce the suffering and involvement of children in armed conflict.

${ }^{1}$ Colleen C. Maher (1989), The Protection of Children in Armed Conflict: A Human Rights Analysis of the Protection Afforded to Children in Warfare, B.C Third World, p. 297.

${ }^{2}$ Marsha L. Hackenberg (2000), Can the Optional Protocol For the Convention on the Rights of Child Protect the Ugandan Child Soldier, Law Review, p. 417,418.

${ }^{3}$ Dorcas B. Mulira (2007), International Legal Standards Governing the Use of Child Soldiers, Georgia Law, p.4 
The pressing and much publicized problem of child soldiers in international law involves two related and interlocking issues: the criminal liability of those who recruit child soldiers and the culpability of child soldiers for war crimes. Contention over the age at which a person is no longer considered a child comprises an important part of international legal discourse surrounding these two issues. Even where there is a general agreement that children should not be used as child soldiers, the understanding of who precisely is a child remains an unsettled issue. For example, the Convention on the Rights of Child, which defines childhood as beginning at birth and ending at age eighteen, also provides an explicit exception to this general definition by setting age fifteen and below as the prohibited age of recruitment for child soldiers ${ }^{4}$. Much of the discourse about child soldiers is dominated by the global focus on the need to offer an umbrella of protection to "children".

\section{Child Soldiers and International Human Rights Law}

Developments in human rights law and humanitarian law applicable to children took place almost simultaneous to but distinct from each other. These two branches of international law are not the only sources of law applicable to children, but currently they are the main sources at issue. Cohn and Goodwin Gill explain further:

"There is no single source for the international law of child, which means it must be looked for in specific and general treaties, in the broad field of human rights at both universal and regional levels, in the rules international humanitarian law, in customary international law and practice of state". ${ }^{5}$

The first attempt to create an extended universal definition of childhood came with the Convention on the Rights of Child (CRC) 1989. The CRC created the first international definition of a child as encompassing "every human being below the age of eighteen years" 6 The Convention on the Rights of Child is commonly said to embody four basic sets of universal rights for children: the rights of participation, protection, prevention and provision. ${ }^{7}$ The right of participation includes the right to participate in decision-making and the right to freedom of conscience. The rights of protection and prevention deal with protecting children from exploitation and abuse. The right of provision addresses the right of access to key resources such as food, shelter, health care, and education. According to CRC these rights apply to all children below age eighteen. Although there are several articles that ipso facto preclude the possibility of recruitment ${ }^{8}$, article 38 takes the conspicuous step of venturing into or invoking international humanitarian law.

There are two recent legal developments which stand separate from but yet relate directly to human rights law and international humanitarian law, the Rome Statute International Criminal Court, which entered into force July 2002 and recent decision by Sierra De Leone Special Court which ruled the prohibition of child soldier recruitment under the age of fifteen to be customary law. The International Labor Organization (ILO) created treaties regarding the protection of children from illegal labor, including child soldiering. The first of these Conventions, No. 138, sets out that no child below the age of fifteen can be employed in any economic sector. ${ }^{9}$ Convention No. 182 further sets out that dangerous or harmful employment-prostitution, combat, mining or pornography is banned for all children under the age of eighteen years. ${ }^{10}$ While both of these Conventions, on their face, may appear capable of making a real difference in the lives of children, they have presented a number of problems. Convention No. 138 was not accepted by any of Asian, African and Latin American countries where child labor is the most prevalent. In addition, while Convention No.182 clearly forbids the involvement of children less than eighteen combat, the practice continues to occur.

It is also important to point out that international law has become quite clear what constitute a combatant or a soldier, there is no such clear understanding of or category for someone who is both a child and a soldier. The very concept of child-soldier or child-combatant does not exist within the law, with the exception of provisions made for

\footnotetext{
${ }^{4}$ Convention on the Rights of Child, Nov.20, 1989, Art. 1

5 llene Cohn, Guy Goodwin-Gill (1997), Child Soldiers: the role of children in armed conflicts, Clarendon Press, p.55-56.

${ }^{6}$ Convention on the Rights of Child (1989), Article 1, p.1.

${ }^{7}$ Geraldine Van Bueren (1998), The International Law on the Rights of Child, Martinus Nijhof Publisher, p.15.

${ }^{8}$ For example, Article 19(1) requires States Parties to take " all appropriate... measures to protect the child form all forms of physical or mental violence, injury or abuse...", Articles 3(2), 6 and 16 are among those articles which are similar in this regard.

${ }^{9}$ Convention Concerning Minimum Age of Admission to Employment, adopted June 26, 1973, Article 2(3)

${ }^{10}$ Convention Concerning the Prohibition and Immediate Action for the Elimination of the Worst Forms of Child Labor, adopted June 17, 1999, Art. 3
} 
captured, armed minors.

\section{Problems Facing Children in Situations of Armed Conflict}

\subsection{Extent of Child Soldering Worldwide}

Children who are on the move because they are displaced and impoverished by war or civil unrest are particularly vulnerable for abduction and forced child soldering. During the civil war that lasted seventeen years in Sierra Leone, more than 1 million children were displaced and twenty-five thousand children (some as young as six) were abducted and forced to become members of armed groups. ${ }^{11}$ While the participation of children in armed conflict is not new, it occurred in World War II, child soldering today is a widespread phenomenon, prevalent particularly in developing countries where political, economic and social instability are more commonplace and where approximately half the population are children. Children have served in government forces paramilitaries or in opposition force in Colombia, Mexico, Peru, Turkey, Algeria, Angola, Chad, Sierra Leone, Uganda, Iran, Iraq, India, Nepal, Pakistan, Yugoslavia etc. ${ }^{12}$

The use of child solders is still occurring in the Europe, Africa, the Middle East, Central Asia and Asia. In our days, a big problem on child soldier's phenomenon displays the case of Joseph Kony in Uganda. Joseph Kony and the LRA are most infamous for their activities in Uganda since the mid-to-late 1980s. In the past several years, however, the group has focused more on terrorizing regions in the Democratic Republic of the Congo, South Sudan, and the Central African Republic. The LRA's typical modus operandi has involved kidnapping children to serve as armed combatants and/or sex slaves. ${ }^{13}$ In 2005, the ICC issued a warrant for Kony's arrest on 12 counts of crimes against humanity and 21 counts of war crimes. The court also issued warrants for four of Kony's deputies in the LRA.

Despite international optimism, finding and prosecuting Kony is only the first step. His arrest will not guarantee the end of the LRA, though arresting him and his deputies would be a significant achievement. The ICC and its work represent only one part of the international justice system; the others involve disarming rebel groups and implementing effective government structures to address the problems at their roots. "KONY 2012" has started to bring one aspect of conflict resolution into the public mind but there are other issues that will eventually have to be addressed.

\subsection{Abuses of child soldiers}

Child soldiers are subjected daily to dehumanizing atrocities. They are often abducted from their own home, tortured, indoctrinated with brutality, forced to become intoxicated with mind-altering drugs, threatened with death and/or dismemberment if they don't fight, forced to return to their own village to witness or participate in the death of their own family members. Children are required to kill friends who don't obey the commanders and made to watch the punishment of other child soldiers who attempt in vain to escape. Child soldiers are brainwashed thoroughly and brutally until their ethics and moral values become so distorted that they believe doing evil is good.

Brainwashing is accomplished by desensitizing children to the sight and commission of atrocities. Some children who try to escape are reportedly boiled alive and other child soldiers are then forced to eat the human flesh as part of their training. ${ }^{14}$ Young girls are abducted as well and make up forty percent of the ranks of armed groups in some countries. ${ }^{15}$ In Uganda, Ethiopia and El Salvador almost a third of child soldiers are young girls, who are raped given to military commanders as wives and victimized by sexual violence on a daily basis. Girl soldiers encounter serious abuse including forced pregnancy. Girl soldiers are often used as domestic servants and sex slaves during conflict. When they are infected with HIVIAIDS they are usually not treated. These victimized girl soldiers require stabilization and special attention after their demobilization.

These children are victims of inhumane brainwashing and merciless combat training that makes them robotically obey orders to kill innocent victims just to stay alive. These children undergo a terrifying initiation that consists of killing or

\footnotetext{
${ }^{11}$ Susan Tiefenbrun (2007), Child Soldiers, Slavery and Trafficking of Children, Fordham International Law Journal, Vol. 31 ,p.421.

${ }^{12}$ Human Rights Watch (2007) Where Child Soldiers Are being Used, Available at: http://www.hrw.org/campaigns/crp/where.htm

13 The Harvard Independent (March 25, 2012), Kony 2012: The Legal Case, Available at: http://www.harvardindependent.com /2012/03/kony-2012-the-legal-case/

${ }^{14}$ Economist (2005), Justice v Reconciliation: Hunting Uganda's Child Killers , p. 41

${ }^{15}$ U.N Office for the Coordination of Humanitarian Affairs (2007), Africa: Fighting for Children, Available at: http://irinnews.org /report.aspx?reportid=70016
} 
raping a close relative. They are forced to participate in acts of extreme violence and barbarity of rap, beheadings and the burning of people alive.

\subsection{The Root Causes of the Use of Child Soldiers}

Children's recruitment in armed conflict is either by force (conscription) or voluntary (enlistment), even though voluntary recruitment is often coupled with hidden forms of coercion. Armed militia, police or army cadres arbitrarily seize young recruits from the streets, schools or orphanages. Children forcibly recruited cannot exercise a choice or give their consent to serve in armed conflict. Nerveless, consent is the key element required to determine whether the recruitment of children for armed conflict actually constitutes trafficking and not just the smuggling of migrants, in accordance with the definition of trafficking set forth in Palermo Protocol. ${ }^{16}$ If a child is voluntary recruited and takes up arms "consensually", he or she may not be protected under the trafficking statutes.

Various factors in a child's environment may cause her to join an armed group voluntarily. The child's parental and family background, peer groups, school and religious community can strongly influence his decision to fight. Poverty, ignorance, intellectual and developmental immaturity and a lack of formal education prevent children from making an informed choice or even understanding why they are fighting. ${ }^{17}$ Children without schooling are prone to recruitment, like the many children in Sierra Leone when three hundred schools were closed due to damage.

Several interrelated factors explain the underlying causes of the rise in the abduction and use of child soldiers. Social disruption and governmental failures to protect children and adults have been attributed to globalization, to the increase in number and length of wars and to the spread of fatal diseases like AIDS, all of which create familial and generational disconnections leaving many potential child recruits available for abduction. The social and psychological effects of war can create a need for children to join a group especially an army that promises to provide relative security and stability. The huge number of children available and the military successes of these child soldiers have accelerated the trend toward recruiting young soldiers. The rise of a new type of armed warfare that is more brutal and lasts much longer than typical wars has encouraged military leaders to rationalize the forced recruitment and use of children as a low cost military measure that enables them to mobilize and generate force.

Children are often recruited as soldiers for purely military reasons. The technological advances in weaponry and the prevalent use of small arms and light weapons facilitate the increasing use of child soldiers. Such weapons allow small children to shoot steady streams of bullets with the mere pull of the trigger. Children are recruited because they are small and can be used as guinea pigs by their leaders who force them to the front lines or to minefields ahead of older troops while their commanders stay behind. ${ }^{18}$

\subsection{Individual Criminal Responsibility}

Individual Criminal Responsibility is, in fact, a core legal concept in international criminal law. Without going too deeply into legal aspects individuals who ordered, planned committed or aided and abetted in the planning preparation or execution of a crime under Article 2 to 4 of the Statute of the International Criminal Tribunal for Rwanda ${ }^{19}$, Articles 2 to 5 of the Statute of the International Criminal Tribunal for the former Yugoslavia ${ }^{20}$, and Articles 6 to 8 of the Rome Statute of the International Criminal Court ${ }^{21}$ can be found criminally responsible for such a crime, despite the fact that they may not have pulled the trigger. This reality is important when considering the issue of finding child soldier recruiters responsible

\footnotetext{
16 Protocol to Prevent, Suppress and Punish Trafficking in Persons, Especially Women and Children (2000), Article 3: "Trafficking in persons" shall mean the recruitment, transportation, transfer, harboring or receipt of persons, by means of the threat or use of force or other forms of coercion, of abduction, of fraud, of deception, of the abuse of power or of a position of vulnerability or of the giving or receiving of payments or benefits to achieve the consent of a person having control over another person, for the purpose of exploitation. Exploitation shall include, at a minimum, the exploitation of the prostitution of others or other forms of sexual exploitation, forced labor or services, slavery or practices similar to slavery, servitude or the removal of organs.

${ }_{17}$ Tiffany A. Richards (2004), The War is over but the Battle has just begun: Enforcing a Child's Right to Education in the Wake of Armed Conflict, L. Rev, p.205-206

${ }^{18}$ Susan Tiefenbrun (2007), Child Soldiers, Slavery and the Trafficking of Children, Fordham International Law Journal, vol.31, p. 431

${ }^{19}$ Statute of the International Criminal Tribunal for Rwanda, Nov. 8, 1994, art. 2-4

${ }^{20}$ Statute of the International Criminal Tribunal for the Former Yugoslavia, May.25, 1993, art. 2-5

${ }^{21}$ Rome Statute of the International Criminal Court, July. 17, 1998, art. 6-8.
} 
for acts of genocide, crimes against humanity and war crimes.

The most obvious cases of individual criminal responsibility can be found in the ICTR and ICTY. It should be noted, however, the legal concept of individual criminal responsibility recently became an issue in the ANFAL trial, particular concerning the prosecution's clarity of the chain command. ${ }^{22}$ For a successful prosecution of individual criminal responsibility, there must be an international and national desire to hold an individual accountable for his misconduct. While the initial sentiment has been to hand individuals over to an applicable tribunal, demonstrated by the recent flux of international bodies, militarily tribunals have proven to be as legally appropriate as an international tribunal. ${ }^{23}$ In regards to child soldiers, it must be considered whether an international desire to hold them accountable for their actions exists.

\section{Conclusion}

The issue of child soldiers is not going to disappear anytime soon. What must be done, as a strong first step, is to stop the recruitment of these children. If there is no further recruitment, than a significant portion of children will not become child soldiers in combat situations. Despite a profusion of domestic and international laws that prohibit the use of child soldiers, this inhumane and widespread practice is likely to increase in the future due to the economics of war. Considering that the use of child soldiers is "rooted in the endemic competition for economic resources" and fueled by the huge profits from the traffic in drugs, weapons, and human beings, any proposal to eradicate child soldiering must necessarily involve economic solutions in order to effectuate real change in this hideous practice and to firmly re-establish traditional ethics relating to the protection and preservation of children's rights.

In order to eliminate child soldiering, the global community must address the protection of the child victims by strengthening compliance and implementation of international humanitarian laws, human rights norms, slavery conventions, trafficking conventions, international criminal laws, and fair labor laws that are applicable to children's rights and child soldiering. The Rome

Statute of the International Criminal Court established child soldiering as a war crime in 2002. The international ad hoc tribunals and the permanent International Criminal Court should prosecute individuals and States Parties engaging in child soldiering and widely publicize the outcome of its cases.

The most important fact to remember is that child soldiers are children. Children, at the end of the day, likely do not have the capacity to meet necessary elements for genocide, crimes against humanity and war crimes. Even if a court is persuaded that they meet such a stringent test, duress must be kept in mind. We must keep and utilize the defenses available to child soldiers in order to ensure that only those most deserving of punishment are in fact punished. No matter how one tries to spin the scenario, most child soldiers are not joining armies of their own accord. It is not their hands pulling the trigger; it is largely the hands of misguided adults who have forced these children into one of the most horrific situations in this world, namely war.

\section{References}

Colleen C. Maher (1989), The Protection of Children in Armed Conflict: A Human Rights Analysis of the Protection Afforded to Children in Warfare, B.C Third World, p. 321

Ilene Cohn, Guy Goodwin-Gill (1997), Child Soldiers: the role of children in armed conflicts, Clarendon Press, p.238

Geraldine Van Bueren (1998), The International Law on the Rights of Child, Martinus Nijhof Publisher, p. 435

Susan Tiefenbrun (2007), Child Soldiers, Slavery and Trafficking of Children, Fordham International Law Journal, Vol. 31

Geoffrey S. Corn, Jan E. Aldykiewicz (2002), New Options for Prosecuting War Criminals in Internal Armed Conflict, Parameters, Vol.32, no.1

Statute of the International Criminal Tribunal for Rwanda, Nov. 8, 1994, art. 2-4

Statute of the International Criminal Tribunal for the Former Yugoslavia, May.25, 1993, art. 2-5

Rome Statute of the International Criminal Court, July. 17, 1998, art. 6-8.

Convention Concerning the Prohibition and Immediate Action for the Elimination of the Worst Forms of Child Labor, adopted June 17, 1999

Convention Concerning Minimum Age of Admission to Employment, adopted June 26, 1973

Convention on the Rights of Child 1989

Mulira, Dorcas B., (2007), "International Legal Standards Governing the Use of Child Soldiers" LLM Theses and Essays. P. 88. http://digitalcommons.law.uga.edu/stu_IIm/88

22 Letter from Richard Dicker, Dir., International Justice Program, to President of Iraq Tribunal (March 28, 2007), Available at: http://www.electron-iciraq.net/news/internationallaw/Anfal_Proceedings_Raise_Concerns_Open_Letter_to_th_2972_printer.shtm

${ }^{23}$ Geoffrey S. Corn, Jan E. Aldykiewicz (2002), New Options for Prosecuting War Criminals in Internal Ärméd Conflicts, p.39-42 